\title{
Research on the Effects, Problems and Strategies of Comprehensive Reform Policy of Private Education in China
}

\section{-Based on the Empirical Investigation and Analysis of 25 Schools in City X}

\author{
Huapeng Dai ${ }^{1,2^{*}}$, Ting $\mathrm{Li}^{1}$, Yu Wen ${ }^{3}$ \\ ${ }^{1}$ The Faculty of Education, Southwest University, Chongqing, China \\ ${ }^{2}$ Institute of Education Policy, Southwest University, Chongqing, China \\ ${ }^{3}$ School of International Studies, Zhejiang University, Hangzhou, China \\ Email: "daihuapeng@gmail.com
}

Received 21 August 2014; revised 7 October 2014; accepted 20 October 2014

Copyright (C) 2014 by authors and Scientific Research Publishing Inc.

This work is licensed under the Creative Commons Attribution International License (CC BY). http://creativecommons.org/licenses/by/4.0/

(c) (i)

\section{Abstract}

While the comprehensive reform policies of private education have achieved remarkable results, further reforms are needed to promote the better development of non-governmental education. The research group carried out fieldwork in 25 schools in city $X$, where the policy implementation, effects of implementation, existing problems and causes were all thoroughly analyzed. The results show that classified management, teachers' social insurance and government purchase services have been properly implemented. However, limited school autonomy, inequality of payment between teachers of private and public schools, investment and financing difficulties, lack of financial support, and limited land share remain serious problems. Therefore, it is argued that the allocation distribution for public and private schools should be adjusted, the team dynamic of private school teachers should be further strengthened, and schools should be administered independently. It also requires broadening the investment and financing channels, adopting a system of mixed ownership, and developing an innovative system to manage schools. The first step in this process requires following the direction of optimizing the quality of private schools and achieving equalization with public schools. Second, existing mechanisms should be enhanced to link government-, department-coordination, grassroots innovation and the participation of the public. Third, according to the specific regional situation, resources should be allocated to promote the formation of mutual development patterns for public and private education in China.

\footnotetext{
${ }^{*}$ Corresponding author.
}

How to cite this paper: Dai, H.P., Li, T. and Wen, Y. (2014) Research on the Effects, Problems and Strategies of Comprehensive Reform Policy of Private Education in China. Open Journal of Social Sciences, 2, 88-97. 


\section{Keywords}

\section{Private Education, Reform, System, Mechanism}

\section{Introduction}

This study aims to fully investigate the implementation status and existing problems of the comprehensive reform policy of private education in China, to provide the nation and local districts practical cases as reference for new policy making and reforms of private education.

The development of China's private education is a result of the release of private space under the economic structure transformation [1]. However, current public education resources cannot keep pace with demand from Chinese society [2]. Moreover, limits on the amount of China's resources devoted to public education are having the effect of promoting further expansion of private education [3]. The Outline of National Medium-and Long-Term Program for Education Reform and Development says that: "More efforts on supporting private education, making and bettering preferential policies that can promote private education, promoting trials of reinforcing systems to run a school, and opening trials of classifying profit-making and non-profit-making private schools are needed.” In 2010, Notice on Pilot Reform of Education System of the Country issued by the general office of the State Council (Ref. No.48) also requires the improvement of the developmental environment of private education and deepening schooling system reform [4]. According to all the relevant studies, we can find that this is mainly related to studies on the historical development of the overall reform policies of private education, the current problems, strategies and suggestions, and private education's reform trials in different areas [5]. Research on reform policy and mechanism of private education has been sufficiently conducted in foreign countries [6], where private schools are mainly run through donations. But in China, private education is mostly carried out through investment. On one hand, the experience in other countries of supporting private education on donation does not seem to suit a system where private education depends on investment. On the other hand, China is lacking the data on models of private education's reinforcement. Therefore, the study group undertook local studies on private education's reform policies in order to describe the real situation of reform over the past three years. The study group then analyzed the issues objectively and developed a summary of typical experience with the reform process. Ultimately, it is anticipated that the results of the study will help the government in developing and improving policies that will deepen the reforms and foster private education that is balanced, popular, and fair.

\section{Research Design}

\subsection{Research Methodology}

\subsubsection{Interview}

Two interview outlines were developed, which were used separately in meetings with department directors and with CEOs and principals. Recordings made during the meetings with the personnel from related departments include comments on the publishing background information, implementation process, and the effect of the comprehensive reform policy of private education in city X. Also, the main challenges and specific difficulties with policy implementation were thoroughly analyzed. The research group visited 25 first-tier pilot schools in county A and district B, interviewed the school CEOs, principals and teacher representatives. They verified collected questionnaire data and reviewed the schools' three-year plans, and took note of different opinions and suggestions.

\subsubsection{Questionnaires}

According to the situation of educational reform of 25 private schools in city X, two sets of questionnaires were developed which are "Questionnaire A" and "Questionnaire B" for follow-up investigation on comprehensive reform of private education in city X. Questionnaire A was distributed to the educational bureaus of counties and districts in city $\mathrm{X}$ for investigation of the general situation of counties and the educational departments. Questionnaire B was given to the 25 private schools for understanding the policy implementation over the past 
two years. Questionnaire A mainly includes the structure of teacher teams in the local private schools, financial support to the private school teachers, investment in private education, and conditions of registration for social insurance of private school teachers. Questionnaire B generally covers attributes of the legal status of pilot schools, institutional development, school teachers' mobility, fiscal support, school supplementary investment, and fee scale.

\subsection{Object of Study and Sampling}

Taking into account the economic difference of different counties and districts, with overall consideration of the representativeness of the sample districts and feasibility of the investigation and survey, city $\mathrm{X}$ and county $\mathrm{B}$ were selected to conduct the survey. The research group chose different locations, diverse schooling stages (kindergartens, primary and middle schools) and various posts (directors of different departments, school CEOs, principals and teacher representatives) as survey targets and had informal discussions with them followed by on-the-spot investigation at those schools. Samples include 19 schools in county A which consists of 13 kindergartens, six nine-year coherent schools, and six schools in district B which are two kindergartens and four middle schools.

\subsubsection{Data of Regional Private School Teachers}

The number of private school teachers in county A is 5306 (121 with permanent posts) in year 2010, and 7034 (257 with permanent posts) in 2013. In district B, the numbers are 781 (13) and 1077 (38). In both regions the number of private school teachers, including those with permanent posts, has dramatically increased.

\subsubsection{Data of Regional Private Schools and Students}

County A has 217 private kindergartens and 18 private primary and middle schools with the at-school student number 650,000. District B has 68 private kindergartens, 15 private full-time schools and 60 private training institutions. Further details are indicated in Table 1.

\section{Results and Analysis}

\subsection{Remarkable Achievement}

\subsubsection{Developing Matching Solutions and Classified Management Implement}

A misplaced legal entity status is the source problem that has caused difficulties in the development of private education in China. This has resulted in private schools not having preferential policies for land use and taxes that public schools have, but still having to pay relevant taxes as enterprises, which is an issue of inequality between the two systems. There are 59 private schools selected as pilot schools (taken in two turns) in county A, among which, 52 schools are registered as legal institutions, while seven are registered as legal enterprises.

\subsubsection{Enhanced Financial Support}

The survey displays that in the past three years, there have been annually increases in fiscal support to the private schools from the government, which has solved the issue of low funding. Details of fiscal support are indicated in Figure 1.

\subsubsection{A Gradual Rise of Education Project-Guided Investment}

Of the schools in county A, one school has totally invested more than 50 million yuan in 2012 and has carried forward 6 major investment projects with a total investment amount of 212.5 million yuan. The investment of private education in the county increased to 627.44 million yuan since 2010. One school in district B financed 6 million yuan, which made a "breakthrough of zero" on the private education investment. Details of investment are indicated in Figure 2.

\subsubsection{Implementation of Preferential and Support Policies}

The research shows that in terms of land use rights, the county government provided the Longgang Zhen Kangle kindergarten and Dongcheng Kindergarten a schooling land of 12.5 acres by means of administrative allocation. Last year, by land auction the new district got 25 acres of land for the construction of a private school. 
Table 1. Number of students at different schooling stages in private schools in district B in 2013.

\begin{tabular}{cccc}
\hline & Attending students & Registered students & Percentage \\
\hline Private high schools & 2021 & 6824 & $29.62 \%$ \\
Private 9-year compulsory schools & 11,126 & 43,373 & $25.65 \%$ \\
Private kindergartens & 11,829 & 14,562 & $81.23 \%$ \\
\hline
\end{tabular}

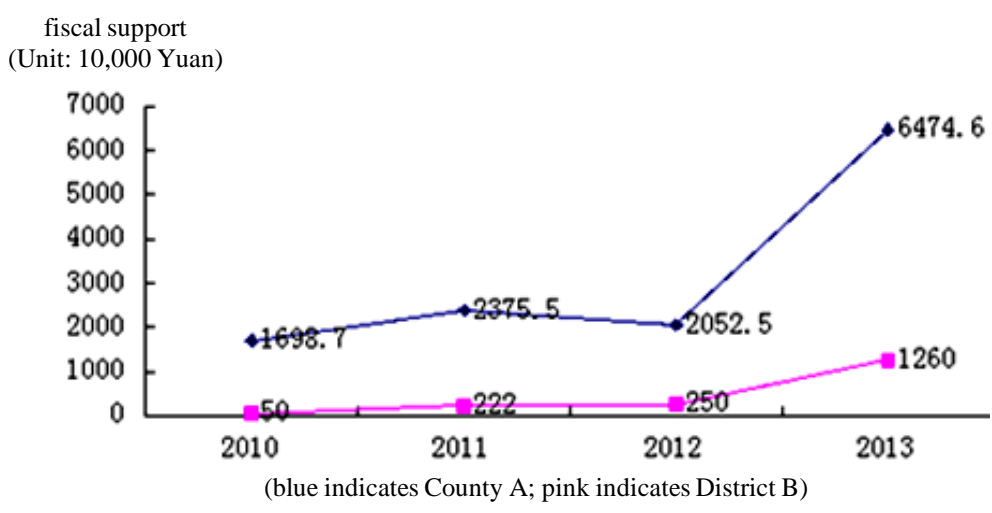

Figure 1. Local fiscal support to private schools in County A and District B in 2010-2013.

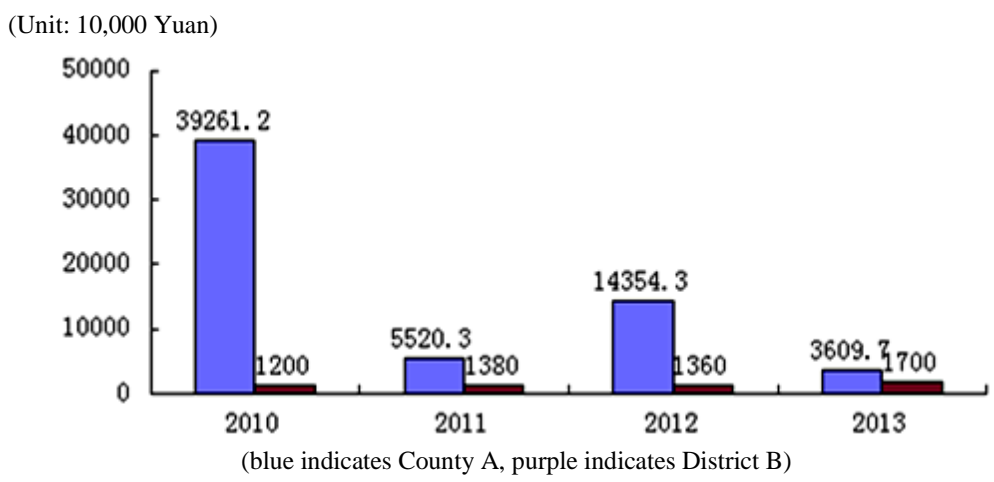

Figure 2. Investment of private schools in County A and District B in 20102013.

\subsubsection{Gradual Growing Coverage of Social Insurance Policy}

The survey indicates that in respect to implementing the new policy on social insurance, there are 661 private school teachers in the county who registered for institutional social insurance. From 2010 to 2013, the number of teachers who registered for social insurance in both of the two regions has increased on an annual basis. However, there are differences among the various schools. Details of registration are indicated in Figure 3.

\subsubsection{Enhancing Teachers' Team Dynamic}

In 2010, county A implemented a policy that the standardized performance salary of private school teachers is 70 percent of what public schools teachers earn at the same level. In 2013, the salary was separately increased by 1000 yuan according to different schooling stages. Currently there are 903 teachers contracted with personnel agencies. In the past two years, 40 public school principals and head teachers, as well as more than 300 visiting public school teachers, went to work or to teach in pilot schools. These private school teachers receive equal treatment to public school teachers in terms of training and job evaluation. In total, 1135 teachers participated in specific training and 3445 full-time preschool teachers and nursery governesses participated in the entire staff training. Details of staffing are indicated in Figure 4. 


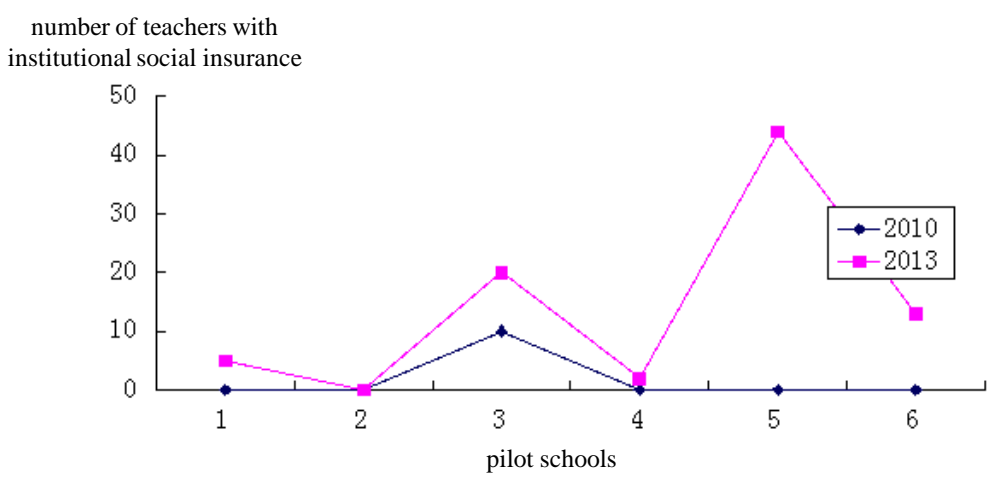

Figure 3. Registration of social insurance of private schools teachers in 20102013 (district B).

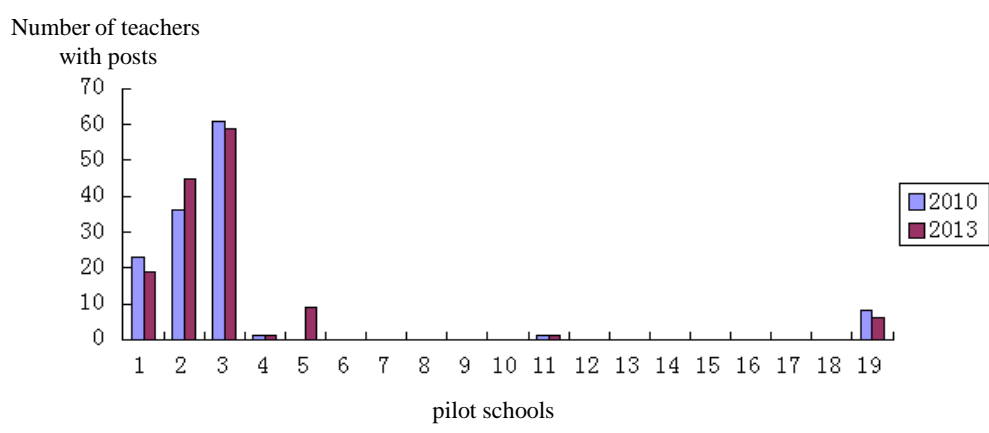

Figure 4. Post staffing of private school teachers at County A in 2010-2013.

\subsection{Prominent Problems}

Although the comprehensive reforms of China's private education system have made remarkable progress, problems such as indefinite legal status and unclear property ownership rights have emerged in private education management. Possible reasons could be the conception restriction, incomplete policies and regulations, and overly restrictive institutional mechanisms. Such issues have correlated at various levels and collectively have had significant impact.

\subsubsection{Restricted Autonomy in Running Private Schools}

The first issue relates to restrictions of financing autonomy. During the survey of department directors, school CEOs and teachers in school visits, many schools indicated that the cost of teachers' social insurance caused financial strain on the schools. As a result, schools want greater flexibility and autonomy on certain issues of financing to guarantee the efficient and sustainable school management. The second issue concerns the schools' limited autonomy in recruiting students. It covers two important aspects: cross-district student recruitment and examination-based student recruitment. The research indicates that most schools in both districts are willing to recruit students from other districts. Some schools indicated that if public schools can recruit students from other districts, then private schools should also be permitted to do so. The autonomy issue is particularly prominent in districts where schools are generally demanding certain autonomy in running schools because of the lack of good students to recruit. However, it is understood that the government has concerns about some pre-school students will be recruited into primary schools, and that those schools may charge more for the students, which will worsen the inequity of education.

\subsubsection{Inequality of Payment between Teachers of Private and Public Schools}

The survey results indicated that private schools have a lack of permanent posts (official planned job vacancies) available for fulltime teachers, which results in significant loss of teachers. The research shows that many teachers chose to take recruitment tests for public school positions because there are no permanent posts in private schools. The teacher loss in private schools has therefore been a very serious problem. Some interviewees 
state that the loss of excellent teachers who were meticulously trained by private schools has had a huge impact on teaching quality of the school, our students, and school administrators.

There is also no guarantee on the sustainable social insurance policy. Although the government has been increasing fiscal support from 2011 to 2013 for private schools to purchase social insurance for teachers, it is hard to guarantee the persistence of the fiscal support. Besides, it remains difficult to solve problems such as social insurance for foreign teachers, standards of price difference, and the modes of social insurance after the combination of institutional insurance and enterprise insurance. Details of teacher loss are indicated in Figure 5.

\subsubsection{Delayed Fiscal Support and Weak Supporting Force}

Some schools stated they have not received fiscal support from the local government. Although the government has been increasing fiscal support, some schools indicated the government funding to purchase services is not yet in place. For instance, one school in district B has not received the fiscal support for 2013. The standard of fiscal support is undefined. It is difficult to meet the financial needs of the schools that lack funding when minimum supporting criteria were used. It appears that the government seldom approves the amount of fiscal support for schools operating as private schools.

\subsubsection{Insufficient Land Quota and Restricted School Spatial Development}

Most private school administrators indicated that the government assigned quota for land use is restricted which strongly limited schools' physical development. According to the local economy, the land quota that is distributed to county A and district B is limited. It is even harder for the school administrators to break through the barriers of land quota. At the same time, related departments and institutions are lacking strong support and cooperation with private schools and often implement procedural restrictions.

\subsubsection{Unclear School Property Right Ownership}

According to Chinese law, private schools are registered as private non-enterprise legal entities. As non-profit organizations, the properties should be continuously used for programs that support the public good. In this way, the investment is equivalent to a donation. However, statistics from the investigation group of the "Education, Science, Culture and Public Health Committee” of The National Peoples' Congress indicates that more than 90 percent of private schools in China are run by investments. The ownership of school property rights is not clear, and there is a lack of guarantee on the assets invested by contributors [7]. Moreover, when there is a change of school administrators and/or a school is terminated by law, no specific approach is available to deal with school properties, especially with the value-added parts of investment from the contributors.

\subsubsection{Unreasonable Allocation Distribution for Public and Private Schools}

There are allocation differences between public and private schools that create an unreasonable distribution. In the rural and poor areas, which have few sources of students, the private schools are hard to develop, yet public schools cannot guarantee the minimum requirement of education, leaving the students without an inclusive education. Meanwhile, public schools are competing with private schools for teachers and students in the districts or areas where private schools have opportunities for development and marketability. This has made private schools an even adverse living environment and has hindered their development. Private education covers very few schooling stages of compulsory education (primary schools and middle schools) and high schools, which has caused a vertical imbalance in schooling stages. In 2010, the whole province where city X is located had 8527 private schools, or 24.2 percent of the total schools. The number of private school teachers is 21.2 percent of the total teachers in the province. Among all the private schools in this province, 65.4 percent are preschools, 32.7 percent are higher education, 19 percent are high schools, and only 10.7 percent are compulsory education. Details of distribution in different school stages are indicated in Figure 6.

\subsubsection{Indefinite Authority of School Administrators}

The relationship between school runners/investors and school administrators are as capital and professional managers, whose rights and responsibilities and practices may affect the quality of how the school is run. During the survey, many private school personnel mentioned the issue of rights and responsibilities of school administrators. The main problems seem to include excessive authority of investors over the authority and autonomy of administrators. It is difficult to achieve a balance between these two groups and this has led to an effect on the 


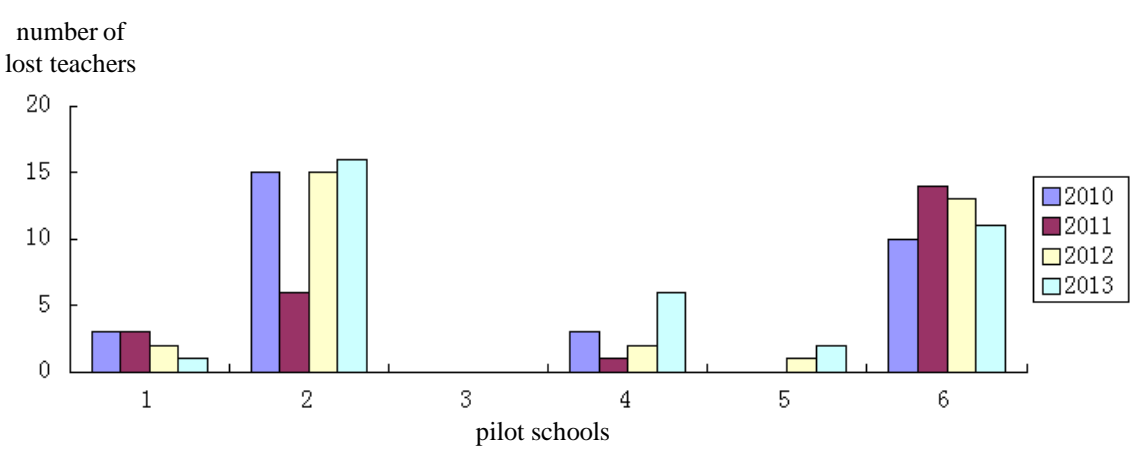

Figure 5. Loss of teachers from pilot schools at District B in 2010-2013.

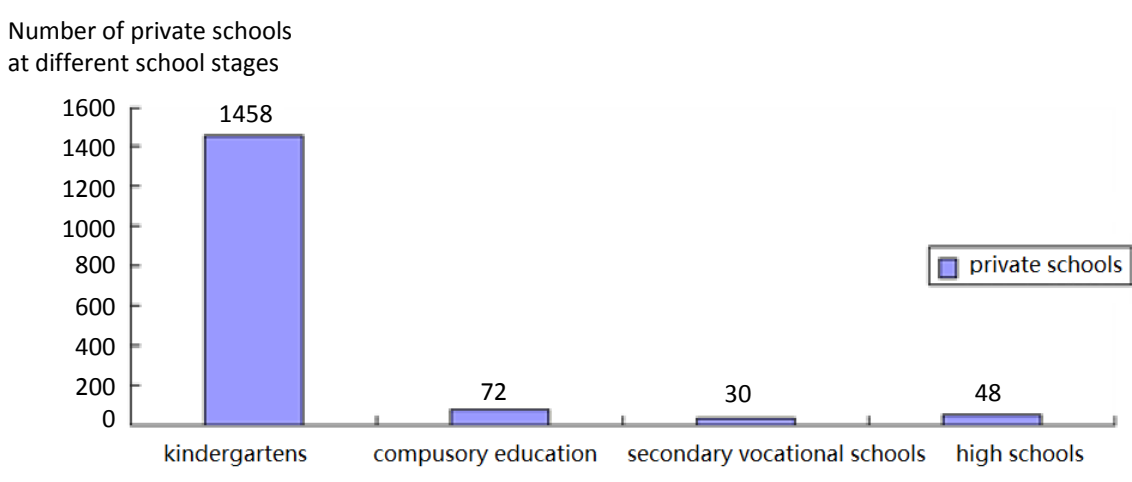

Figure 6. Distribution of different schooling stages in private schools in city X in 2012.

teaching in schools. This is not only a problem of individual conception but also a reflection of an imbalanced institutional relationship.

\section{Strategies and Suggestions}

Based on the survey results and analysis of private education, three items should be clarified: the fundamental aim of the reform policies; the effective approaches; and the key objectives. At the government level, it should focus on the innovation of institutional mechanisms, the improvement of public policy for education, and the optimization of the environment for the development of private education. At the school level, importance should be placed on the innovation of quality and management, the establishment of a modern school system, and the creation of diverse and resources for private education. At the societal level, it requires a focus on the innovation of school management by a variety of forces, the introduction of the investment and financing mechanism, and broadening the space for the development of private education.

\subsection{Adjust the Geographical Layout of Public and Private Schools and Realize High Quality Private Education and Equalized Public Education}

\subsection{1. "Public Aided Private Running" in City and "Public Aided Multi-School Running" in Rural Areas, and Adjusting the Layout of Urban and Rural Areas}

Relying on its resource advantage, public schools can keep the minimum operation in rural areas and not compete in the market of private education. According to the urban and rural reality it should be a priority to synchronize the urban kindergarten establishment and residential development and construction, and freely transfer the supporting kindergartens to the administrative department of education. Subsequently, the city would establish a kindergarten system of "Public aided private running". This allows private actors to run the kindergartens through a bidding mechanism. The practical advantages of the city's population, a large demand for student enrolment, and a good economic foundation would actively encourage social forces to run the private kindergartens at high grade and large scale.

While in the countryside, a kindergarten mechanism of "public aided multi-school running" is recommended. 
According to the lower number of students, the geographic area covered, and changing flexibility in rural areas, the kindergartens at the township center should mainly be publicly run by the government, and on this basis, open up more channels for multiple ways for the kindergarten to be run. A unified layout and management are required for both public and private owned kindergartens at village centers.

\subsubsection{Set up More Private Middle Schools and High Schools and Adjust the Proportion inside Private Schools}

According to the research results, there is a large proportion of private kindergartens and private primary schools in city X, but private middle schools and high schools are at a much smaller proportion. In view of the differences in proportion of different educational stages in private schools, an ideal approach would be more public schools and stronger private schools at the pre-school stage, fewer public schools and more private schools at the stage of compulsory education, and stronger public schools and transferred private schools at high school stage.

\subsection{Complete Fiscal Support Policy [8] and Improve Public Finance System}

Limited by economic and social development, current private education in China has not yet had access to the same conditions as developed countries that mainly rely on donations to run private education. Therefore, facing the status of schools running by multilateral investment and not recognizing the legal status of for-profit schools is impractical. Removing the legal aspects from the reality has caused obstacles to the development of private education. A system of public support based on fair and coordinated development should be established.

\subsubsection{Adjust Minimal Criteria of Fiscal Support}

Since different private schools have different levels of funding requirements, the government should take into account the quality of school administration and properly consider the funding difficulties and options to adjust financial support, not just simply follow the standard of three to five times of the current students' average budget.

\subsubsection{Provide Land Use Right and Implement Preferential Policies on Taxes and Fees}

Regarding the right to land use, the most prominent problem is the conflict of legal requirements. For instance, diploma-granting private schools are required to pay 25 percent enterprise income tax; while non-diploma private schools need to pay 3.3 percent business tax plus 17 percent enterprise income tax. An equal preferential policy on tax should be applied to the non-profit private schools and public schools.

\subsubsection{Establish Early-Warning Mechanism for Fiscal Support and Improve Public Finance System of Private Schools}

With the rise in financial subsidies for the private schools, which are also increasing in number, the accumulated supporting amount of the government would reach its limit of fiscal support. This usually results in a freeze of funding without any early-warning, which certainly creates obstacles in the development of private schools. It is also the issue that private school administrators and teachers registered to social insurance program are mostly concerned with. According to the revenues and expenditures of the government and predictions on future economic development, the upper and lower limits of government fiscal support should be measured and calculated, followed by the establishment of an early-warning mechanism.

\subsection{Strengthen Teachers' Team Build and Explore Multi-Modes for School Running}

Teachers' team dynamic is the core element in private education development and is also critical to the improvement of education quality. Currently, the instability of teachers' team dynamic is the bottleneck that restrains the private education development. The root reason is the unequal payment of retired teachers of private schools and public schools. The private schools in China need to actively explore new modes of running schools, using the experience of other countries for reference, such as "famous school-private school" partnership or private school running with public school support.

\subsubsection{Strengthen Teachers' Team Dynamic}

Teachers should be better recognized and should receive guaranteed remuneration. In the current national policy 
system, the main way to ensure the institutional identity of private school teachers is to use a personnel agency system for teachers and allow them to have the equal legal status as the public school teachers. Teachers should also be encouraged to volunteer teaching in rural schools in order to increase teacher mobility. A mechanism for teacher mobility should be established between private and public schools, whose seniority and teaching years should be continuously calculated. Teacher training should be strengthened for private school teachers and to establish an introduction mechanism for excellent talent. By the end of October 2013, there were 962 teachers in county A and 272 teachers in district B from various private schools who had completed teacher qualification training. The number of trained kindergarten teachers is 745 in county A and 650 in district B, but it is still far from being enough.

\subsubsection{Establish Multi-School Running Modes and Deepen School Running System}

Industry and enterprises should be encouraged to participate in running public schools. Public schools and private schools should be encouraged to support each other and administer schools jointly by various means such as purchasing services from one another. New methods of managing and administrating schools should be encouraged, which might include commissioned management and international cooperative school running.

\subsection{Guarantee School Running Autonomy and Regulate School Administration}

\subsubsection{Ensure School Running Autonomy and Construct the Index System of Education Quality Evaluation}

According to the relevant national regulations and requirement of administering schools, private schools should be encouraged to explore new options for student recruitment, teaching management, personnel distribution, and international cooperation and exchanges. This allows greater independence in school management, and fosters a situation that schools are run according to law, that the government is administrating legally, and the society is supervising according to law. In addition, the teaching quality evaluation index of public schools should be referred to establish an index system of teaching quality and optimize the school administration quality.

\subsubsection{Clarify the Property Ownership and Establish Financial Supervision Mechanism}

The current financing difficulties of private education are due to the unclear legal entity status of schools and undefined school property rights. This leads to difficulties in terms of assigning property rights and also makes it difficult to implement accounting regulations and school financial supervision. Ownership of private schools accumulated shall be identified according to the law. The exit mechanism of private schools should be established and improved. Property management should be strengthened in accordance with the law. Only with clear property rights will the interests and benefits of investors be protected and will the enthusiasm of investors on school running be fully activated.

\subsection{Promote the Investment and Financing System Reform and Attract Social Resource Input in Education}

To perfect the education investment and financing platform, with the aid of the Education Development and Investment Group Co., Ltd., financial institutions should be encouraged to provide innovative financial products, and actively provide financial services to private schools. New tools should be explored such as private school loans on mortgage by using non-teaching assets, pledge loans on charging rights and intellectual property rights, and credit loans. Also, schools should be allowed to explore setting up Guarantee Corporations in different regions to support the private education and to conduct intensive development. By broadening the financing channels, reforming the system of investment and financing it will lead to new social resources in education.

\subsection{Institute the Mixed Ownership and Innovate School Running System and Mechanism}

The "Decision of CPC Central Committee on Major Issues in Deepening the Reforms" says that "a mixed ownership economy is the important form of the basic economic system in our country and is conducive to all kinds of capital to promote each other for common development”. Actively developing the mixed ownership economy has an important guiding significance for social forces to run education. All kinds of school administrators should be supported to run private education by various means such as sole proprietorship, joint venture, coop- 
eration, and joint-stock system. It also requires increases to the institutional mechanism of innovation, establishment and perfection of the educational and public policy, construction of a modern school system, the broadening of financing channels, and attraction of social forces to invest in education, which ultimately leads to a positive level of mutual development of public and private education [2].

\section{Conclusion}

In conclusion, city X combined with the actual situation of the local economic and social development, highlighted its own city's features in the aspects of school administration system reform, investment and financing environment optimization, and government support funds; it also kept overall consistency with the macro education system while stressing the relative flexibility of the local education system. City $\mathrm{X}$ has made a positive contribution to four areas including expanding the supply of educational resources, providing a variety of choices, innovating institutional mechanism of education, and inspiring education activity. To form a good pattern of mutual development of public and private education with the government as the main school administrator and the society as active participants, it requires the following actions: insisting on developing in the direction of optimizing private education quality and equalization of public education; developing a linkage mechanism of toplevel design, government led, departments coordinated, grass-roots innovation, and participation of social forces; fully considering the regional situation and market characteristics; and using mechanisms of market regulation and resource allocation.

\section{References}

[1] Dong, S.Z. (2010) The Development of Private Education Calls for Greater Legislation Support. Research in Educational Development (RED), 8, 1.

[2] Shan, M. (2004) The Present Situation, Problem, and Trend of Private Education. Zhejiang Social Sciences (ZSS), 3, 129-134.

[3] Wang, Y. (2013) On the Reasonable Path of Private Education in China-Taking Comprehensive Reform Pilot Work for Private Education in City X as an Example. Research in Educational Development (RED), 3, 20-24.

[4] Wang, W.Y. (2007) Optimization of the Policy Environment to Promote Reasonable Transformation of Private Education. Research in Private Education (RPE), 3, 7-13.

[5] Wu, H. (2005) Five Institutional Innovation of Chinese Private Education. Research in Educational Development (RED), 3, 17-23.

[6] Xu, H. (2004) Present Situation, Reform and Developing Trend of Foreign Private Schools. Private Higher Education Research (PHER), 1, 64-66.

[7] Shen, J.G. and Zhong, H. (2011) Property Right of Legal Person of Private Schools and the Classified Management of Private Education. Educational Research (ER), 12, 20.

[8] Xing, S.Z. (2005) Speeding up the Pace of the Local Legislation of Private Education and Promoting the New Development of Private Education. Research in Educational Development (RED), 20, 1-4. 
Scientific Research Publishing (SCIRP) is one of the largest Open Access journal publishers. It is currently publishing more than 200 open access, online, peer-reviewed journals covering a wide range of academic disciplines. SCIRP serves the worldwide academic communities and contributes to the progress and application of science with its publication.

Other selected journals from SCIRP are listed as below. Submit your manuscript to us via either submit@scirp.org or Online Submission Portal.
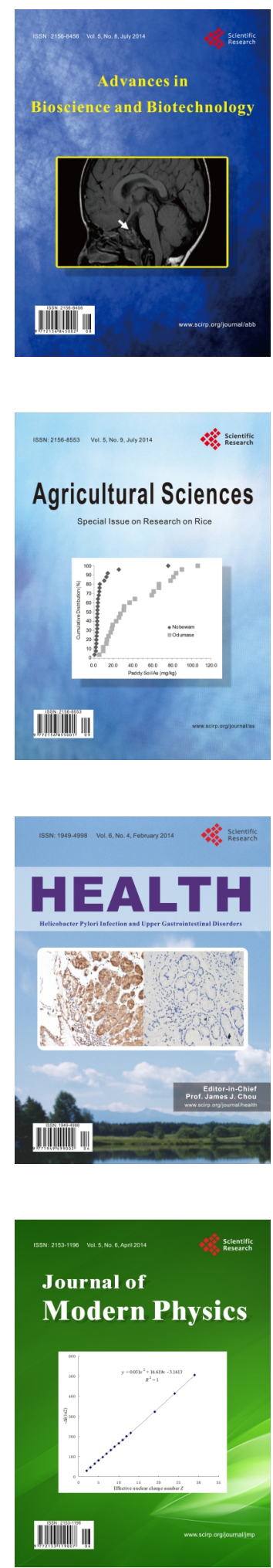
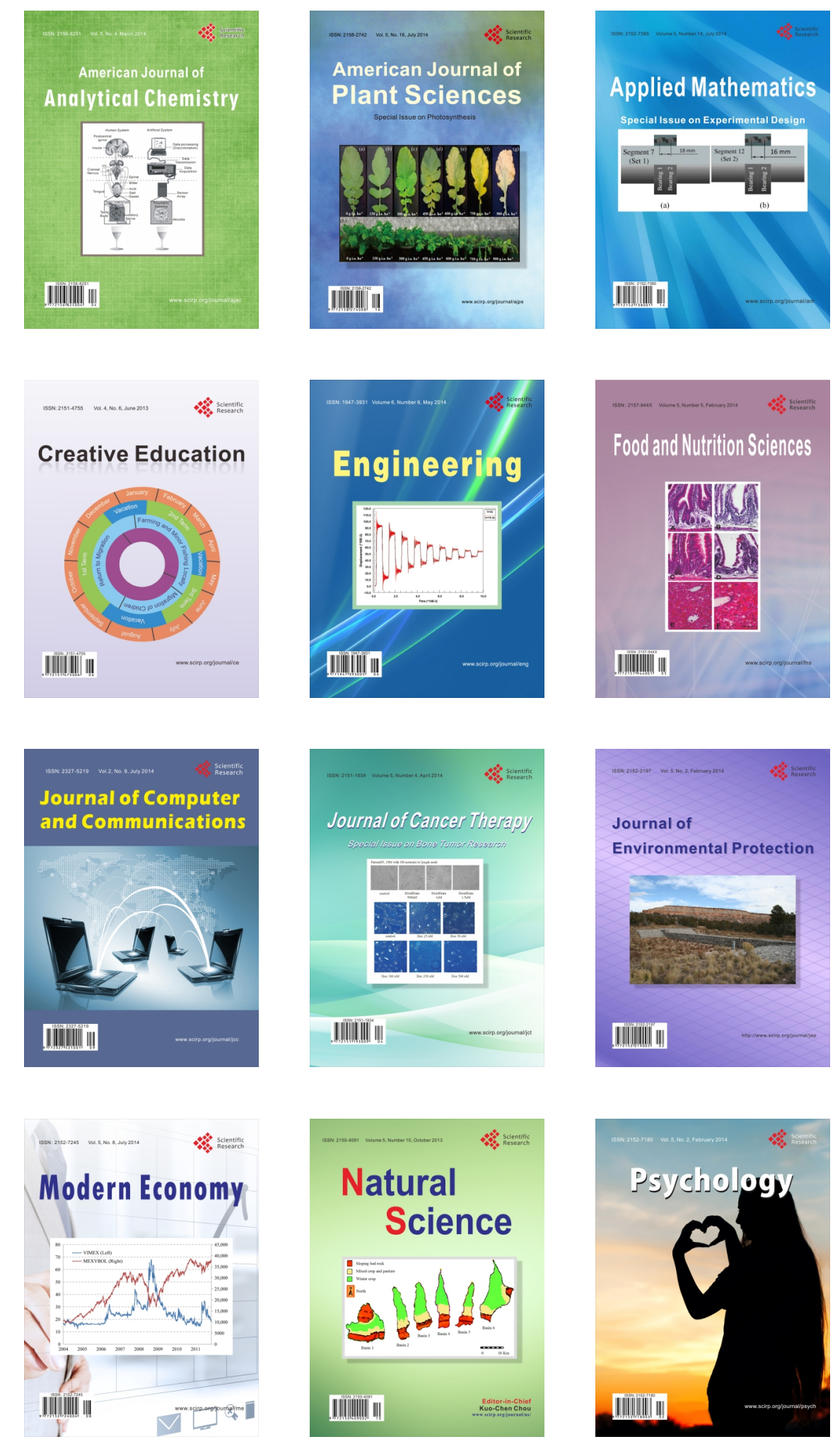